\title{
Perbedaan Kualitas Hidup Pasien Hipertensi Ringan yang Melakukan Exercise dan Tidak Melakukan Exercise di Posyandu Lansia
}

\author{
Saiful Hidayat $^{1}$, Yuliana Heri Suselo ${ }^{2}$, Dhoni Akbar Ghozali ${ }^{3}$ \\ 1.Program Studi Kedokteran, Fakultas Kedokteran, Universitas Sebelas Maret \\ 2. Bagian Fisiologi, Fakultas Kedokteran, Universitas Sebelas Maret \\ 3. Bagian Anatomi, Fakultas Kedokteran, Universitas Sebelas Maret \\ Korespondensi : saifulhidayat@student.uns.ac.id
}

\begin{abstract}
ABSTRAK
Pendahuluan: Hipertensi diderita oleh sekitar 1,13 milyar orang di seluruh dunia. Prevalensi terbanyak pada lansia dan menurunkan kualitas hidup mereka. Exercise meningkatkan kualitas hidup melalui peningkatan kesehatan fisik dan mental. Penelitian ini bertujuan untuk membuktikan kualitas hidup pasien hipertensi ringan yang melakukan exercise lebih baik dibandingkan yang tidak melakukan exercise di Posyandu Lansia.

Metode: Penelitian ini merupakan penelitian eksperimental quasi dengan posttest only control group design. Subjek adalah wanita berusia 45-70 tahun dengan hipertensi ringan, mampu membaca dan menulis, tidak merokok, tidak rutin meminum obat anti hipertensi, dan tanpa penyakit terminal. Pada kelompok pertama terdapat kriteria tambahan yaitu rutin mengikuti kegiatan senam lansia selama satu tahun. Subjek berjumlah 35 orang yang dibagi dalam dua kelompok, kelompok pertama sejumlah 18 orang mendapatkan perlakuan berupa exercise berdurasi 10 menit sebanyak tiga kali seminggu selama empat minggu, kelompok kedua sejumlah 17 orang sebagai kontrol. Penelitian dilakukan di Posyandu Lansia di wilayah kerja Puskesmas Pucang Sawit, Surakarta, Indonesia. Kualitas hidup diukur menggunakan kuesioner SF-36 versi Bahasa Indonesia yang terdiri dari delapan domain yaitu fungsi fisik, peran fisik, peran emosional, energi, kesehatan emosional, fungsi sosial, nyeri, dan kesehatan umum. Data dianalisis menggunakan uji t independent dan Mann Whitney $(\alpha=0,05)$.

Hasil: Kualitas hidup kelompok pertama lebih tinggi dibandingkan kelompok kedua pada semua domain, namun hanya tiga domain yang menunjukkan perbedaan signifikan: fungsi fisik $(87.59 \pm 11.63$ vs $62.31 \pm 31.13 ; \mathrm{p}=0.003)$, peran fisik $(75.46 \pm 33.64$ vs $47.06 \pm 35.22$; $\mathrm{p}=0.013)$, dan energi $(74.72 \pm 14.50$ vs $63.42 \pm 13.76$; $\mathrm{p}=0.016)$.
\end{abstract}

Kesimpulan: Pasien hipertensi ringan yang melakukan exercise memiliki kualitas hidup yang lebih baik dibandingkan yang tidak melakukan exercise di posyandu lansia.

Kata kunci: exercise, hipertensi, kualitas hidup, lansia

\section{ABSTRACT}

Introduction: Hypertension affects around 1.13 billion people worldwide. The prevalence mostly are elderly and reduce their quality of life. Exercise improves quality of life through improving physical and mental health. This study aims to prove the quality of life of patients with mild hypertension who exercise were better than those who do not exercise at Posyandu Lansia.

Methods: This study was a quasi-experimental study with posttest only control group design. Subjects were women aged 45-70 years with mild hypertension, literate, do not smoke, do not regularly take anti-hypertensive drugs, and without terminal illness. In the first group there was an additional criteria, that was had been exercising regularly for one year. Thirty-five subjects were divided into two groups, the first group of 18 people received treatment in the form of 10 minutes of exercise three times a week for four weeks, 
Hidayat, et al., Perbedaan Kualitas Hidup Pasien Hipertensi Ringan yang Melakukan Exercise dan Tidak Melakukan Exercise di Posyandu Lansia

the second group of 17 people as controls. The research was conducted at Posyandu Lansia in the working area of Puskesmas Pucang Sawit, Surakarta, Indonesia. Quality of life was measured using the Indonesian version of the SF-36 questionnaire which was consisted of eight domains, namely physical function, physical role, emotional role, energy, emotional health, social function, pain, and general health. Data were analyzed using independent $T$ test and Mann Whitney $(\alpha=0.05)$.

Results: Quality of life in the first group was higher than the second group in all domains, but only three domains showed significant differences: physical function $(87.59 \pm 11.63 \mathrm{vs}$ $62.31 \pm 31.13 ; p=0.003)$, physical role $(75.46 \pm 33.64$ vs $47.06 \pm 35.22 ; p=0.013)$, and energy (74.72 \pm 14.50 vs $63.42 \pm 13.76 ; p=0.016)$.

Conclusion: Patients with mild hypertension who exercise have a better quality of life than those who do not exercise at Posyandu Lansia.

Keywords: elderly, exercise, hypertension, quality of life

\section{PENDAHULUAN}

Hipertensi diderita oleh sekitar 1,13 milyar orang di seluruh dunia ${ }^{1}$. Prevalensi penderita hipertensi lebih banyak pada populasi lanjut usia dan mengakibatkan penurunan kualitas hidup mereka ${ }^{2}$. Penderita hipertensi ringan adalah mereka yang memiliki tekanan darah 140-159/90-99 $\mathrm{mmHg}^{3}$.

Penderita hipertensi ringan, sedang maupun berat memiliki kualitas hidup yang lebih buruk dari pada individu yang sehat ${ }^{4}$. Kualitas hidup penderita hipertensi bergantung pada beberapa hal di antaranya adalah nilai tekanan darah, ada tidaknya kerusakan organ, komorbid, dan pengobatan yang diterima ${ }^{2,5}$. Beberapa literatur menyebutkan bahwa exercise yang teratur mampu meningkatkan kualitas hidup pasien dengan penyakit kronis seperti gagal jantung, penyakit paru obstruktif kronis (PPOK), hipertensi pulmonal dan kanker secara signifikan $^{6,7,8,9}$. Peningkatan kualitas hidup pada pasien dengan penyakit kronis tersebut terjadi karena exercise mampu meningkatkan kesehatan fisik dan mental ${ }^{10,11,12}$. Peningkatan kesehatan mental dapat terjadi melalui mekanisme peningkatan endorfin, peningkatan termogenesis, peningkatan mitokondriagenesis, aktivasi Mammalian Target of Rapamycin (mTOR), dan memodulasi aksis Hipotalamik-Pituitari-
Adrenal (HPA) ${ }^{10,11}$. Sedangkan, peningkatan kesehatan fisik diperantarai oleh beberapa mekanisme, yaitu sebagai buffer terhadap stress, optimalisasi respons fisiologis dan neuroendokrin terhadap stress, mempromosikan kondisi anti inflamasi, serta meningkatkan neuroplastisitas dan ekspresi faktor-faktor pertumbuhan ${ }^{12}$.

Berdasarkan uraian di atas, didapatkan informasi bahwa exercise mampu meningkatkan kualitas hidup melalui efeknya pada kesehatan fisik dan mental. Oleh karena itu, penelitian ini bertujuan untuk mengetahui perbedaan kualitas hidup antara pasien hipertensi ringan yang melakukan exercise dan tidak melakukan exercise di posyandu lansia.

\section{METODE}

Penelitian ini merupakan penelitian eksperimental quasi dengan posttest only control group design. Penelitian ini dilakukan di posyandu lansia di wilayah kerja Puskesmas Pucang Sawit, Surakarta, Indonesia.

Kriteria subjek penelitian ini adalah wanita berusia 45-70 tahun dengan hipertensi ringan, mampu membaca dan menulis, tidak merokok, tidak rutin meminum obat anti hipertensi, tidak memiliki penyakit terminal, dan telah rutin mengikuti kegiatan senam lansia selama satu tahun untuk kelompok pertama. 
Hidayat, et al., Perbedaan Kualitas Hidup Pasien Hipertensi Ringan yang Melakukan Exercise dan Tidak Melakukan Exercise di Posyandu Lansia

Teknik sampling yang digunakan adalah purposive sampling. Jumlah sampel dalam penelitian ini dihitung menggunakan software OpenEpi untuk penghitungan mean difference dengan confidence interval (CI) $95 \%$, power $80 \%$, dan rasio sampel satu. Dari hasil penghitungan, didapatkan jumlah sampel minimal untuk total kedua kelompok dalam penelitian ini adalah 30 orang.

Subjek kemudian dibagi menjadi dua kelompok. Kelompok pertama mendapatkan perlakuan berupa exercise berdurasi 10 menit sebanyak tiga kali seminggu selama empat minggu, sedangkan kelompok kedua sebagai kontrol $^{13}$

Kualitas hidup diukur menggunakan kuesioner SF-36 versi Bahasa Indonesia yang terdiri dari delapan domain yaitu fungsi fisik, peran fisik, peran emosional, energi, kesehatan emosional, fungsi sosial, nyeri, dan kesehatan umum ${ }^{14}$. Data dianalisis menggunakan uji $\mathrm{t}$ independent dan Mann Whitney dengan tingkat kemaknaan $\alpha=0,05$.

\section{HASIL}

Subjek penelitian adalah warga di wilayah kerja Puskesmas Pucang Sawit yang berusia 45-70 tahun dengan hipertensi ringan. Pada awalnya terdapat 45 orang yang bersedia ikut serta menjadi subjek penelitian yang semuanya adalah perempuan, namun terdapat 6 orang dari kelompok pertama dan 4 orang dari kelompok kedua yang drop out. Sehingga tersisa 18 orang pada kelompok pertama dan 17 orang pada kelompok kedua.

Tingkat pendidikan subjek bervariasi dari SD hingga SMA. Dari 18 orang yang tergabung dalam kelompok pertama terdapat 5 orang dengan pendidikan terakhir SD (28\%), 2 orang dengan pendidikan terakhir SMP (11\%), dan 11 orang dengan pendidikan terakhir SMA (61\%). Pada kelompok kedua, 11 orang di antaranya memilliki pendidikan terakhir SD (65\%), sedangkan 6 orang sisanya memiliki pendidikan terakhir SMA (35\%).
Homogenitas antar kelompok dianalisis menggunakan uji $\mathrm{t}$ independent dan uji Mann Whitney dengan tingkat kemaknaan $\alpha=0,05$. Hasil analisis tersebut ditunjukkan pada tabel di bawah:

Tabel 1. Karakteristik antar kelompok

\begin{tabular}{lccc}
\hline & $\begin{array}{c}\text { Kelompok } \\
1(\mathrm{~N}=18)\end{array}$ & $\begin{array}{c}\text { Kelompok } \\
2(\mathrm{~N}=17)\end{array}$ & $\begin{array}{c}\text { Nilai p } \\
(\mathrm{CI} 95 \%)\end{array}$ \\
\hline Usia & $53,61 \pm$ & $57,71 \pm$ & $0,17 *$ \\
& 3,80 & 5,67 & \\
Tekanan & $148,29 \pm$ & $146,40 \pm$ & $0,51 *$ \\
sistolik & 6,63 & 8,65 & \\
Tekanan & $84,71 \pm$ & $88,00 \pm$ & $0,41 * *$ \\
diastolik & 4,85 & 8,37 & \\
* Uji t independent & & \\
** Uji Mann Whitney & &
\end{tabular}

Dari hasil uji analisis tersebut didapatkan nilai $\mathrm{p}>0,05$ untuk semua karakteristik subjek penelitian. Hal ini menunjukkan bahwa tidak terdapat perbedaan yang bermakna pada karakteristik subjek antara kelompok pertama dan kedua, sehingga dapat disimpulkan bahwa sampel dalam penelitian ini homogen.

Dari tabel 2 dapat dilihat bahwa ratarata skor domain kualitas hidup kelompok pertama lebih tinggi dibandingkan kelompok kedua pada semua domain.

Dari hasil uji t independent dan Mann Whitney didapatkan bahwa meskipun rata-rata skor semua domain kelompok pertama lebih tinggi dibandingkan dengan rata-rata skor semua domain pada kelompok kedua, namun hanya tiga domain yang menunjukkan perbedaan signifikan: fungsi fisik (87.59 \pm 11.63 vs $62.31 \pm 31.13 ; \mathrm{p}=0.003)$, peran fisik (75.46 \pm 33.64 vs 47.06 $\pm 35.22 ; \mathrm{p}=0.013)$, dan energi $(74.72 \pm 14.50$ vs $63.42 \pm 13.76$; $\mathrm{p}=0.016$ ). 
Hidayat, et al., Perbedaan Kualitas Hidup Pasien Hipertensi Ringan yang Melakukan Exercise dan Tidak Melakukan Exercise di Posyandu Lansia

Tabel 2. Rata-Rata dan Nilai P Masing-Masing Domain pada Kedua Kelompok

\begin{tabular}{llccc}
\hline No & \multicolumn{1}{c}{ Domain } & $\begin{array}{c}\text { Kelompok 1 (N=18) } \\
\text { Mean } \pm \text { ISD }\end{array}$ & $\begin{array}{c}\text { Kelompok 2 (N=17) } \\
\text { Mean } \pm \text { ISD }\end{array}$ & $\begin{array}{c}\text { Nilai p (CI } \\
95 \%)\end{array}$ \\
\hline 1 & Fungsi Fisik & $87,59 \pm 11,63$ & $62,31 \pm 31,13$ & $0,003^{* *}$ \\
2 & Peran Fisik & $75,46 \pm 33,64$ & $47,06 \pm 35,22$ & $0,013^{* *}$ \\
3 & Peran Emosional & $77,58 \pm 36,23$ & $52,73 \pm 39,13$ & $0,052^{* *}$ \\
4 & Energi & $74,72 \pm 14,50$ & $63,42 \pm 13,76$ & $0,016^{* *}$ \\
5 & Kesehatan Emosional & $84,22 \pm 10,76$ & $73,00 \pm 17,72$ & $0,080^{* *}$ \\
6 & Fungsi Sosial & $71,94 \pm 20,50$ & $63,08 \pm 21,84$ & $0,225^{*}$ \\
7 & Nyeri & $70,83 \pm 21,00$ & $60,00 \pm 27,04$ & $0,193^{*}$ \\
8 & Kesehatan Umum & $75,25 \pm 10,44$ & $65,58 \pm 16,76$ & $0,056^{* *}$ \\
\hline
\end{tabular}

* Uji t independent

** Uji Mann Whitney

\section{PEMBAHASAN}

Kualitas hidup terdiri dari dua komponen, yaitu komponen fisik yang terdiri dari domain fungsi fisik, peran fisik, nyeri dan kesehatan umum; serta komponen mental yang terdiri dari domain energi, fungsi sosial, peran emosional dan kesehatan mental ${ }^{15}$. Kualitas hidup pasien hipertensi dipengaruhi oleh beberapa faktor, di antaranya adalah usia, jenis kelamin, tingkat pendidikan, gaya hidup, frekuensi meminum obat anti hipertensi dan efek sampingnya, nilai tekanan darah, serta komorbid $^{2,5}$. Seiring dengan proses penuaan, terjadi perubahan-perubahan fisiologis yang membuat pasien hipertensi lebih rentan terhadap penyakit sehingga kualitas hidupnya menurun $^{2}$. Kemampuan menoleransi penyakit kronis pada perempuan lebih buruk dibandingkan pada laki-laki, akibatnya perempuan lebih terpengaruh secara emosional dibandingkan laki-laki ${ }^{16}$. Pasien hipertensi yang memiliki tingkat pendidikan lebih tinggi memiliki kualitas hidup yang lebih baik, karena memengaruhi kemampuan pasien dalam memahami informasi yang diberikan dan meningkatkan kepatuhan pasien selama pengobatan ${ }^{5}$.
Gaya hidup seperti merokok, konsumsi kafein dan makanan yang mengandung garam tinggi, serta tidak aktif secara fisik mengakibatkan kualitas hidup pasien hipertensi semakin rendah ${ }^{5}$. Penggunaan obat anti hipertensi mampu meningkatkan kualitas hidup pasien hipertensi, namun ketika jumlah dan dosisnya ditingkatkan, efek samping yang timbul justru mengakibatkan kualitas hidup pasien hipertensi menurun ${ }^{5}$. Semakin tinggi tekanan darah pasien, maka risiko terjadinya komorbid akan semakin meningkat, akibatnya kualitas hidup pasien hipertensi akan semakin turun ${ }^{4,5,12}$.

Faktor-faktor yang dapat memengaruhi kualitas hidup pasien hipertensi seperti usia, jenis kelamin, nilai tekanan darah, tingkat pendidikan, frekuensi meminum obat-obatan anti hipertensi dan efek sampingnya, serta komorbid tidak dinilai dalam penelitian ini.

Pada penelitian ini didapatkan bahwa kualitas hidup kelompok pertama lebih tinggi dibandingkan kelompok kedua pada semua domain, namun yang menunjukkan perbedaan signifikan hanya tiga domain, yaitu fungsi fisik, peran fisik, dan energi. Hasil penelitian ini sesuai dengan penelitian yang dilakukan oleh Arija et al. (2018) yang menyebutkan bahwa kualitas hidup pasien hipertensi yang memperoleh intervensi aktivitas fisik memiliki kualitas hidup yang lebih tinggi pada domain fungsi fisik, energi dan persepsi 
Hidayat, et al., Perbedaan Kualitas Hidup Pasien Hipertensi Ringan yang Melakukan Exercise dan Tidak Melakukan Exercise di Posyandu Lansia

kesehatan secara umum dibandingkan kelompok kontrol ${ }^{15}$. Begitu pula dengan penelitian Kaliyaperumal et al. (2016) yang menyebutkan bahwa pasien hipertensi yang rutin berolah raga memiliki kualitas hidup yang lebih tinggi dibandingkan pasien hipertensi yang tidak rutin berolah raga pada domain energi ${ }^{2}$. Akan tetapi, penelitian ini tidak sesuai dengan penelitian yang dilakukan oleh Khalifeh et al. (2015) yang menyebutkan bahwa olah raga teratur berkorelasi positif secara signifikan pada semua domain kualitas hidup 5 . Perbedaan ini mungkin diakibatkan karena dalam penelitian Khalifeh et al. (2015) tidak dijelaskan jenis olah raga teratur yang dilakukan oleh subjek penelitian, yang mungkin berbeda dengan intervensi yang diberikan dalam penelitian ini.

Peningkatan kualitas hidup pada domain fungsi fisik mungkin terjadi karena exercise mampu mencegah timbulnya komorbid melalui efeknya sebagai buffer terhadap stres dan penyakit yang berhubungan dengan stres ${ }^{12}$. Komorbid pada pasien hipertensi menurunkan kualitas hidup pasien hipertensi pada domain nyeri, energi, fungsi sosial dan persepsi kesehatan secara umum ${ }^{2}$. Selain itu, exercise mampu meningkatkan kesehatan fisik, sehingga keterbatasan peran yang timbul akibat masalah fisik akan menurun, yang pada akhirnya meningkatkan kualitas hidup pada domain peran fisik ${ }^{12,17}$. Sedangkan, peningkatan pada domain energi mungkin diakibatkan oleh efek exercise yang meningkatkan perfusi jaringan dan ketersediaan oksigen untuk organ-organ vital, sehingga individu tersebut tidak mudah merasa lelah ${ }^{2}$.

Meskipun tidak berbeda secara signifikan, domain kualitas hidup yang lain seperti peran emosional, kesehatan emosional, fungsi sosial, nyeri, dan kesehatan umum pasien hipertensi ringan yang melakukan exercise juga memiliki skor yang lebih tinggi dibandingkan kelompok kontrol. Hal ini mungkin disebabkan karena dalam penelitian ini tidak dilakukan aktivitas sosio-kultural yang dapat memberi efek peningkatan yang signifikan pada kesehatan mental seperti yang dilakukan oleh Arija et al. (2018) ${ }^{15}$.

Peningkatan pada domain kesehatan emosional mungkin diakibatkan oleh efek exercise pada peningkatan neurotransmitter serotonergik dan adrenergik di otak; serta aktivasi mTOR yang mengurangi stres, depresi, kecemasan, serta memperbaiki fungsi kognisi dan emosi ${ }^{10,11}$. Mekanisme di atas mengakibatkan keterbatasan peran yang timbul karena masalah kesehatan emosional menurun, yang pada akhirnya akan meningkatkan kualitas hidup pada domain keterbatasan emosional ${ }^{11}$.

Peningkatan kualitas hidup pada domain fungsi sosial mungkin terjadi karena aktivitas kelompok seperti yang dilakukan dalam penelitian ini meningkatkan fungsi sosial antar individu melalui tukar pengalaman, pemikiran, dan perasaan yang terjadi selama melaksanakan kegiatan ini ${ }^{15}$. Peningkatan kualitas hidup pada domain persepsi kesehatan secara umum dan nyeri mungkin diakibatkan oleh efek exercise pada pelepasan neurotransmiter seperti serotonin, dopamin, dan noradrenalin yang bekerja pada otak dengan meningkatkan persepsi kesehatan secara umum serta menghambat serabut saraf yang menghantarkan nyeri, sehingga memberi efek anestesi pada derajat tertentu ${ }^{15}$. Selain itu, exercise juga dapat meningkatkan ketahanan terhadap stres fisik dan mental sehingga membuat individu tersebut tidak mudah sakit, yang pada akhirnya akan meningkatkan kualitas hidup pada domain persepsi kesehatan secara umum ${ }^{12}$.

Penelitian ini memiliki beberapa keterbatasan, di antaranya adalah desain penelitian ini merupakan posttest only control group design, sehingga peneliti tidak dapat mengetahui perubahan yang terjadi pada kelompok pertama sebelum dan sesudah intervensi. Intervensi yang diberikan juga masih terlalu minimal dan dalam durasi yang 
Hidayat, et al., Perbedaan Kualitas Hidup Pasien Hipertensi Ringan yang Melakukan Exercise dan Tidak Melakukan Exercise di Posyandu Lansia

relatif singkat, sehingga manfaat exercise pada domain kualitas hidup yang lain seperti peran emosional, kesehatan emosional, fungsi sosial, nyeri, dan kesehatan umum belum bisa diamati pada subjek penelitian.

Keterbatasan lainnya adalah peneliti tidak mengendalikan semua faktor yang dapat memengaruhi kualitas hidup pasien hipertensi, sehingga hasil penelitian ini mungkin terpengaruh oleh faktor-faktor yang belum dikendalikan seperti tingkat pendidikan, gaya hidup, komorbid, penggunaan obat anti hipertensi dan efek sampingnya. Peneliti juga tidak menanyakan apakah saat dilakukan pemeriksaan tekanan darah pasien sedang meminum obat anti hipertensi atau tidak, karena hal ini akan memengaruhi hasil pemeriksaan tekanan darah pasien. Selain itu, peneliti juga tidak melakukan follow-up terhadap aktivitas fisik yang dilakukan oleh subjek dalam kelompok kontrol selama penelitian ini, di mana hal tersebut dapat memengaruhi hasil akhir penelitian ini.

\section{KESIMPULAN}

Berdasarkan hasil penelitian ini maka dapat disimpulkan bahwa kualitas hidup pasien hipertensi ringan yang melakukan exercise lebih baik dibandingkan kualitas hidup pasien hipertensi ringan yang tidak melakukan exercise di posyandu lansia.

\section{UCAPAN TERIMA KASIH}

Penulis mengucapkan terima kasih kepada RAJ Sri Wulandari, dr., M.Sc. selaku penguji yang telah berkenan menguji serta memberikan kritik dan saran yang membangun guna menyempurnakan penelitian ini.

\section{DAFTAR PUSTAKA}

1. WHO. Blood Pressure. 2018 [sitasi Maret 2018]. Diunggah dari: URL: www.who.int

2. Kaliyaperumal S, Hari SB, Siddela PK, Yadala S. Assessment of Quality of Life in
Hypertensive Patients. J. Appl. Pharm. Sci. 2016;6(5):143-147.

3. Soenarta AA, Erwinanto, Mumpuni ASS, Barack R, Lukito AA, Hersunarti N, Pratikto RS. Pedoman tatalaksana hipertensi pada penyakit kardiovaskular. Edisi ke 1. 2015.

4. Wang R, Zhao Y, He X, Ma X, Yan X, Sun $\mathrm{Y}$, et al. Impact of hypertension on healthrelated quality of life in a population-based study in Shanghai, China. Public Health. 2009;123(8):534-539.

5. Khalifeh M, Salameh P, Hajje AA, Awada S, Rachidi S, Bawab W. Hypertension in the Lebanese adults: Impact on health related quality of life. JEGH. 2015;5(4):327-336.

6. Hacker E. Exercise and quality of life. Clin. J. Oncol. 2009;13(6):31-39.

7. Beauchamp MK, Nonoyama M, Goldstein RS, Hill K, Dolmage TE, Mathur S, et al. Interval versus continuous training in individuals with chronic obstructive pulmonary disease - a systematic review. Thorax. 2010;65:157-164.

8. Pandey A, Garg S, Khunger M, Garg S, Kumbhani DJ, Chin KM, et al. Efficacy and safety of exercise training in chronic pulmonary hypertension: systematic review and meta-analysis. Circ. Heart Fail. 2015;8(6):1032-1043.

9. Palmer K, Bowles KA, Paton M, Jepsen M, Lane R. Chronic heart failure and exercise rehabilitation: A systematic review and metaanalysis. Arch. Phys. M. 2018;99(12):25702582.

10. Lloyd BA, Hake HS, Ishiwata T, Farmer CE, Loetz EC, Fleshner M, et al. Exercise increases mTOR signaling in brain regions involved in cognition and emotional behavior. Behav. Brain Res. 2017;323:56-67.

11. Mikkelsen K, Stojanovska L, Polenakovic M, Bosevski M. Exercise and mental health. Maturitas. 2017;106:48-56.

12. Deuster PA, Silverman MN. Biological mechanisms underlying the role of physical fitness in health and resilience. Interface Focus. 2014;4(5).

13. Borjesson M, Onerup A, Lundqvist S, Dahlöf B. Physical activity and exercise lower blood pressure in individuals with hypertension: 
Hidayat, et al., Perbedaan Kualitas Hidup Pasien Hipertensi Ringan yang Melakukan Exercise dan Tidak Melakukan Exercise di Posyandu Lansia

Narrative review of 27 RCTs. Br. J. Sports Med. 2016;50(6) 356-361.

14. Rachmawati Y, Perwitasari DA, Adnan. Validasi kuesioner SF-36 versi indonesia terhadap pasien hipertensi di puskesmas yogyakarta. Pharmacy. 2014;11 (1): 14-25.

15. Arija V, Villalobos F, Pedret R, Vinuesa A, Jovani D, Pascual G, et al. Physical activity, cardiovascular health, quality of life and blood pressure control in hypertensive subjects: Randomized clinical trial. Health Qual. Life Outcomes. 2018;16:184.

16. Bardage C, Isacson DG. Hypertension and health-related quality of life: an epidemiological study in Sweden. J. Clin. Epidemiol. 2011;54:172-181.

17. Garber CE, Blissmer B, Deschenes MR, Franklin BA, Lamonte MJ, Lee IM, et al. Quantity and quality of exercise for developing and maintaining cardiorespiratory, musculoskeletal, and neuromotor fitness in apparently healthy adults: Guidance for prescribing exercise. Med Sci Sports Exerc. 2011;43(7):13341359. 